\title{
Analysis of Chest Tube Scars on the Use of Conventional versus Knotless Methods
}

Analisis Parut Luka Chest Tube pada Penggunaan Metode Knotless Versus Konvensional

\section{Claudia Loho, ${ }^{1}$ Mendy Hatibie, ${ }^{2}$ Adrian Tangkilisan, ${ }^{3}$ Wega Sukanto, ${ }^{3}$ Fredrik G. Langi ${ }^{4}$}

\author{
${ }^{1}$ Program Pendidikan Dokter Spesialis Bagian Ilmu Bedah Fakultas Kedokteran Universitas \\ Sam Ratulangi, Manado, Indonesia \\ ${ }^{2}$ Divisi Bedah Plastik Bagian Ilmu Bedah Fakultas Kedokteran Universitas Sam Ratulangi, \\ Manado, Indonesia \\ ${ }^{3}$ Divisi Bedah Kardio-Toraks-Vaskuler Bagian Ilmu Bedah Fakultas Kedokteran Universitas \\ Sam Ratulangi, Manado, Indonesia \\ ${ }^{4}$ Divisi Kesehatan Masyarakat Bagian Ilmu Bedah Fakultas Kedokteran Universitas Sam \\ Ratulangi, Manado, Indonesia \\ Email: claudiacollinsloho@ gmail.com \\ Received: November 11, 2021; Accepted: February 23, 2022; Published on line: February 25, 2022
}

\begin{abstract}
Removal of chest tube is a one of the most distressing and frustrating experience for patients. Moreover, it has a tendency of scar formation. A relatively new method has been developed using a type of suture without knots (knotless). Assessment of scar is an objective and subjective method performed by using patient and observer scar assessment scale (POSAS). This study was aimed to assess the scars formed due to chest tube removal using conventional and knotless sutures. This was a controlled trial design. The Mann-Whitney test was used to compare the PSOAS scores of scars formed due to conventional and knotless sutures performed by patients and observers after three months, and obtained a p-value of less than 0.05. In conclusion, scar formation due to knotless suture is more acceptable for patients compared to conventional suture among chest tube removal wounds; therefore, the knotless suture can be a cosmetically alternative for wound closure management.
\end{abstract}

Keywords: chest tube; scar tissue; knotless suture; conventional suture

\begin{abstract}
Abstrak: Pelepasan chest tube merupakan hal yang menyakitkan dan pengalaman yang membuat frustasi bagi pasien. Selain itu, tindakan ini berpeluang menyebabkan pembentukan jaringan parut. Telah dikembangkan metode baru dengan material jahitan baru yang tidak perlu disimpul. Penilaian jaringan parut dapat berupa penilaian obyektif dan subyektif dengan menggunakan Patient and Observer Scar Assessment Scale (POSAS). Penelitian ini bertujuan untuk menilai jaringan parut akibat pelepasan chest tube antara penjahitan metode konvensional dan knotless. Desain penelitian ialah controlled trial. Penilaian PSOAS baik dari pasien, observer, atau keduanya dilakukan tiga bulan kemudian terhadap jaringan parut yang terbentuk akibat penggunaan kedua metode. Perbandingan hasil skor PSOAS dianalisis dengan uji Mann-Whitney yang mendapatkan nilai $\mathrm{p}<0,05$. Simpulan penelitian ini ialah pembentukan jaringan parut pada metode knotless lebih akseptabel bagi pasien dibandingkan metode konvensional. Hal ini dapat menjadi salah satu metode alternatif penutupan luka chest tube dengan hasil yang lebih dapat diterima.
\end{abstract}

Kata kunci: chest tube; jaringan parut; metode knotless; metode konvensional 


\section{PENDAHULUAN}

Pemasangan chest tube atau chest drain telah banyak dipraktekkan dan umumnya dokter harus mampu untuk melakukannya dengan aman. ${ }^{1}$ Tindakan ini merupakan suatu prosedur life-saving dan digunakan untuk drainase cairan, darah, atau udara dari rongga pleura. ${ }^{2,3}$

Komplikasi dari chest tube dikategorikan pada pemasangan atau pelepasan. ${ }^{4}$ Pelepasan chest tube merupakan hal yang menyakitkan dan pengalaman yang membuat frustasi bagi pasien. Studi menunjukkan pasien yang menjalani pelepasan chest tube mengalami nyeri mulai dari skala sedang sampai berat. Bekas luka yang tidak enak dilihat juga menyebabkan stres tambahan pada pasien. ${ }^{5}$ Penutupan yang aman dan kosmetik pada bekas luka chest tube telah menjadi hal yang menarik bagi ahli bedah selama bertahun-tahun. ${ }^{6}$

Metode yang paling umum ialah menutup luka dengan kasa vaselin dan plester, namun penyembuhan luka via granulasi menyebabkan hasil yang kurang estetik. Untuk mendapatkan hasil yang baik secara kosmetik diperlukan aproksimasi yang baik dari tepi luka sehingga untuk hal tersebut, teknik penutupan luka dengan penjahitan, stapler, atau gluing setelah pelepasan chest tube telah banyak disarankan, ${ }^{6}$ namun metode konvensional tersebut menyebabkan berbagai efek samping. ${ }^{2}$

Nyeri saat melepas chest tube timbul saat akan mengetatkan jahitan. ${ }^{5}$ Oleh karena itu, Jong Ho Cho mencari metode baru yang dapat mengurangi rasa nyeri dan meninggalkan jaringan parut yang lebih sedikit. Metode yang dikembangkannya ialah dengan menggunakan material jahitan baru yang tidak perlu disimpul. ${ }^{2,7}$ Hal terpenting ialah material ini tidak meninggalkan bekas luka dan mengurangi nyeri. ${ }^{5}$

Atas dasar inilah penulis menganggap perlu adanya data analisis terhadap parut luka chest tube dengan menggunakan metode knotless dan konvensional. Hal ini tentunya dapat membantu para klinisi untuk mengurangi komplikasi pada pasien dengan luka chest tube.

\section{METODE PENELITIAN}

Penelitian ini menggunakan desain controlled trial, dimana pasien dibagi menjadi dua kelompok, yaitu eksperimental dan kontrol. Luka penutupan chest tube group pertama ditutup dengan penjahitan knotless, sementara mereka dalam kelompok kontrol menerima penutupan luka menggunakan metode konvensional. Di luar teknik yang membedakan kedua perlakuan, seluruh pasien mendapatkan perawatan yang sama sesuai prosedur standar penanganan pasien pasca pemasangan chest tube. Penilaian jaringan parut penutupan luka chest tube dilakukan hampir bersamaan oleh dokter dan pasien pada bulan ketiga setelah penjahitan luka selesai dan dilakukan di Badan Layanan Umum Rumah Sakit Umum Pusat (RSUP) Prof. Dr. R. D. Kandou Manado.

Subyek penelitian ialah pasien yang memenuhi seluruh kriteria penelitian ini yaitu pasien yang perlu menjalani prosedur pembedahan pemasangan dan pelepasan chest tube, tidak menderita empiema, tidak memiliki riwayat keloid, tidak memiliki neoplasma daerah payudara, tidak memiliki riwayat pemakaian imunosupresan, dan memberikan persetujuan tertulis untuk berpartisipasi dalam penelitian melalui lembar informed consent.

Setelah pasien dipastikan memenuhi seluruh kriteria penelitian, maka data baseline-nya diambil. Pasien dan hasil insisi didokumentasi. Penilaian jaringan parut pada penutupan luka chest tube kemudian dilakukan pada pertemuan dengan pasien di bulan ketiga.

Analisis desktiptif untuk melihat distribusi variabel penelitian dilakukan secara univariat maupun bivariat. Analisis univariat mencakup penilaian distribusi setiap variabel, termasuk normalitas variabel numerik. Evaluasi ini dilakukan menggunakan uji normalitas Shapiro Wilk. Pada variabel kategori, penilaian distribusi dilakukan melalui tabel frekuensi. Nilai pemusatan dan penyebaran dihitung menurut jenis variabel dan normalitas distribusi untuk yang numerik. Untuk variabel numerik dengan distribusi normal, nilai diberikan 
dalam bentuk mean dan standar deviasi (SD). Bila ketidaknormalan distribusi dapat dibuktikan, nilai median dan rentang antar kuartil (interquatile range, IQR) yang justru diberikan. Untuk variabel kategori, nilai proporsi ditampilkan pada masing-masingnya. Perbedaan karakteristik pasien menurut kelompok perlakuan (penjahitan metode knotless dan konvensional) selanjutnya diberikan dan diuji menggunakan uji $\mathrm{t}$ berpasangan maupun Mann-Whitney $U$ untuk variabel numerik dan uji chi-square atau Fisher's exact untuk variabel kategori.

Perbandingan hasil antara jahitan metode knotless dan konvensional dilakukan pada tingkat bivariat dengan uji dua kelompok yang sesuai dengan jenis variabel yaitu uji t atau padanan non parametriknya. Hasil analisis regresi disajikan sebagai nilai estimasi parameter regresi dan interval kepercayaan 95\% serta nilai p-nya. Software statistik $\mathrm{R}$ versi 3.6.3 merupakan perangkat utama pengolahan data dan analisis statistik.

Penelitian ini telah mendapat persetujuan Komisi Etik Penelitian Kesehatan RSUP Prof. Dr. R. D. Kandou Manado dengan No. 116/EC/KEPK-KANDOU/XI/2020

\section{HASIL PENELITIAN}

Tabel 1 memperlihatkan karakteristik subyek penelitian. Terdapat 36 pasien yang menjalani prosedur pemasangan chest tube menjadi sampel penelitian, dengan jumlah yang sama yakni masing-masing 18 orang mendapat jahitan luka pasca pelepasan kanul dengan metode konvensional ataupun knotless.

Usia rerata pasien ialah hampir 38 tahun dengan variasi yang cukup besar yaitu kurang lebih 14 tahun. Hampir keseluruhannya kecuali empat orang ialah laki-laki (89\%). Dasar pemasangan chest tube cukup bervariasi, tetapi proporsi terbesar $(81 \%)$ atas diagnosis pneumotoraks, hemotoraks, ataupun kombinasi dari keduanya. Daerah paru yang terkena ternyata merata pada lobus dekstra dan sinistra. Tidak tampak perbedaan karakteristik antara pasien yang menerima jenis jahitan konvensional dengan pasien yang lukanya dijahit secara knotless.

Superioritas metode penjahitan luka secara knotless dibandingkan metode konvensional dalam pengontrolan bekas luka khususnya pasca pemasangan chest tube jelas didukung dalam hasil analisis regresi. Terlepas dari waktu penilaiannya, individu dengan jahitan knotless cenderung melaporkan jaringan parut yang kondisinya lebih baik (yakni, skor lebih rendah) daripada pasien dengan jahitan konvensional. Setelah mengontrol variasi usia dan daerah paru yang terkena, penilaian bulan pertama dari pasien dengan jahitan knotless rata-rata lebih rendah sekitar 12,17 poin daripada jahitan konvensional.

Tabel 1. Karakteristik pasien dalam penelitian

\begin{tabular}{|c|c|c|c|c|}
\hline \multirow[b]{2}{*}{ Karakteristik } & \multirow[b]{2}{*}{$\begin{array}{c}\text { Total } \\
(\mathbf{N}=\mathbf{3 6})\end{array}$} & \multicolumn{2}{|c|}{ Jenis Jahitan } & \multirow[b]{2}{*}{$\mathbf{p}^{\mathbf{n}}$} \\
\hline & & $\begin{array}{l}\text { Konvensional } \\
\quad(\mathrm{n}=18)\end{array}$ & $\begin{array}{l}\text { Knotless } \\
(\mathrm{n}=18)\end{array}$ & \\
\hline Usia & $37,6(14,6)$ & $37,7(14,4)$ & $37,4(15,2)$ & 0,955 \\
\hline \multicolumn{5}{|l|}{ Kelamin } \\
\hline Wanita & $4(11)$ & $2(11)$ & $2(11)$ & 1,000 \\
\hline Pria & $32(89)$ & $16(89)$ & $16(89)$ & \\
\hline \multicolumn{5}{|l|}{ Diagnosis } \\
\hline Pneumotoraks & $11(31)$ & $4(22)$ & 7 (39) & \\
\hline Hematopneumotoraks & $7(19)$ & $4(22)$ & $3(17)$ & 0,827 \\
\hline Hemotoraks & $11(31)$ & $6(33)$ & $5(28)$ & \\
\hline Hidropneumotoraks & $7(19)$ & $4(22)$ & $3(17)$ & \\
\hline \multicolumn{5}{|l|}{ Lobus paru } \\
\hline Sinistra & $18(50)$ & $8(44)$ & $10(56)$ & 0,739 \\
\hline Dekstra & $18(50)$ & $10(56)$ & $8(44)$ & \\
\hline
\end{tabular}


Angka ini relatif bertahan pada penilaian hari ketiga. Daerah lobus paru yang terkena dapat memengaruhi hasil penilaian pasien di mana mereka dengan gangguan pada paru sinistra ternyata secara rata-rata memiliki skor sekitar satu hingga dua poin lebih rendah dibandingkan mereka dengan lesi di paru lobus dekstra.

\section{BAHASAN}

Penelitian mengenai metode penutupan luka chest tube yang mengurangi komplikasi nyeri dan jaringan parut kurang akseptabel pada penutupan chest tube pada pasien masih menjadi hal yang menarik bagi ahli bedah selama bertahun-tahun. Berbagai teknik telah banyak digunakan untuk menutup luka pemasangan chest tube. Metode konvensional menggunakan jahitan matras horisontal untuk menutup luka chest tube, namun dengan kerugian meninggalkan jaringan parut yang tidak enak dilihat. Metode knotless kemudian dikembangkan menggunakan barbed suture yang dapat mengurangi tekanan jaringan yang ada sehingga dapat memperpendek fase inflamasi. ${ }^{6}$

Penelitian ini dilakukan terhadap penderita yang perlu menjalani prosedur pembedahan pemasangan dan pelepasan chest tube dan memenuhi kriteria inklusi penelitian dirawat sebagai sampel setelah mereka memberikan persetujuan berupa informed consent. Rekrutmen pasien berlangsung selama masa pengumpulan data hingga jumlah individu memenuhi perhitungan besar sampel. Pada penelitian ini dilakukan pemeriksaan komplikasi penutupan luka chest tube pada dua kelompok berbeda, yaitu dengan metode konvensional dan metode knotless. Total pasien sekitar 36 pasien (18 pasien konvensional vs 18 pasien knotless) diperiksa untuk komplikasi nyeri dan pembentukan jaringan parut. Luka akan mendapat perawatan yang sama dan dikontrol pada tiga bulan kemudian.

Jutaan orang menderita jaringan parut akibat luka bakar, pembedahan, dan trauma. Jaringan parut memiliki dampak luas terhadap individu. Sebagai contoh jaringan parut pada wajah berdampak pada fungsi psikososial dan jaringan parut akibat luka bakar berdampak pada gangguan fungsi fisik.

Mekanisme penyembuhan luka penting untuk diketahui dalam kaitannya dengan pembentukan jaringan parut. Etiologi dan patofisiologi parut hipertrofik dan keloid sampai saat ini masih belum diketahui dengan pasti. Banyak teori yang mengemukakan bahwa fibroproliferasi merupakan penyebab dari parut hipertrofik dan keloid. Fase inflamasi yang memanjang diduga merupakan salah satu penyebab timbulnya scar hipertrofik atau keloid. Meningkatnya jumlah sel-sel imun pada keloid meningkatkan aktivitas fibroblas dan terus terjadi pembentukan matriks ekstrasel.

Metode knotless lebih mudah dan tidak nyeri dibandingkan dengan metode konvensional saat dilakukan pemasangan dan pelepasan chest tube. ${ }^{7}$ Pasien merasa senang karena tidak memerlukan balutan luka setelah chest tube dilepas dan juga sangat nyaman bagi operator karena tidak perlu melepas jahitan dan balutan saat control.

Metode knotless saat ini telah banyak digunakan secara luas di bidang kedokteran lainnya sebagai metode penutupan luka dengan bekas luka yang lebih akseptabel. Sesuai dengan patofisiologinya, barbed suture menghasilkan distribusi tekanan yang sama disepanjang luka, dengan mengurangi tekanan pada kulit, khususnya tepi luka, dan mencegah nekrosis dari strangulasi jaringan dan mikroinfark, sehingga proses inflamasi yang terjadi lebih sedikit. ${ }^{8-10}$ Hal ini akan berpengaruh pada proses penyembuhan lebih baik dan menghasilkan bekas luka lebih kosmetik dan sensasi nyeri akibat bekas luka hipertrofik berkurang ${ }^{1}$

Berdasarkan penelitian sebelumnya, penulis mencoba membuktikan bahwa dengan metode knotless dapat mengurangi komplikasi nyeri dan memberikan hasil jaringan parut yang lebih baik dibandingkan dengan metode konvensional. Dalam kenyataannya jaringan parut tidak hanya dinilai dari karakter fisiknya saja tetapi bagaimana dampaknya terhadap kualitas hidup.

Pada penelitian ini terdapat banyak faktor yang dapat memengaruhi pembentukan jaringan parut, antara lain usia, penyakit penyerta, status gizi, besar luka, dan 
kemampuan operator. Pemasangan chest tube dilakukan oleh residen senior yang telah dilatih mengikuti protokol dan teknik standar sehingga deviasi antar prosedur dapat diminimalisir.

Dari data yang dikumpulkan dan dianalisis dengan uji t berpasangan atau uji Mann Whitney, digunakan penilaian dalam bentuk skor baik dari pasien atau peneliti ataupun gabungan keduanya terhadap perbedaan jaringan parut yang diakibatkan oleh metode knotless dan konvensional. Hasil yang diperoleh menunjukkan bahwa terdapat perbedaan bermakna terhadap pembentukan jaringan parut serta rasa nyeri yang diakibatkan oleh metode konvensional dan knotless dalam pemantauan tiga bulan pasca operasi.

Pada penelitian ini, hasil uji korelasi menunjukkan adanya hubungan linear tinggi $(\mathrm{r}=0,988 ; \mathrm{p}<0,001)$ yang menunjukkan bahwa pembentukan jaringan parut pasca pelepasan chest tube metode knotless lebih baik daripada metode konvensional. Kim et $\mathrm{al}^{2}$ dalam penelitiannya menyatakan bahwa terdapat perbedaan bermakna antara penggunaan metode konvensional dan knotless pada pemantauan tiga bulan yang sejalan dengan hasil penelitian ini.

\section{SIMPULAN}

Pembentukan jaringan parut pada metode knotless lebih akseptabel bagi pasien dibandingkan metode konvensional. Hal ini dapat menjadi salah satu metode alternatif penutupan luka chest tube dengan hasil yang lebih dapat diterima.

\section{Konflik Kepentingan}

Penulis menyatakan tidak terdapat konflik kepentingan dalam studi ini.

\section{DAFTAR PUSTAKA}

1. Laws D, Neville E, Duffy J. BTS guidelines for the insertion of a chest drain. Thorax $\mathrm{J}$. 2003;58(Suppl II):53-9.

2. Kim MS, Cho JH. A New Method of Chest Drain Wound Closure Using Knotless Suture Material. Ann Thorac Surg. 2017 Jan;103(1):e93-5.

3. Porcel JM. Chest tube drainage of the pleural space: a concise review for pulmonologists. Tuberc Respir Dis. 2018;81(2): 106.

4. Ball CG, Lord J, Laupland KB, Gmora S, Mulloy $\mathrm{RH}, \mathrm{Ng} \mathrm{AK}$, et al. Chest tube complications: How well are we training our residents? Can J Surg. 2007;50(6): 450-8.

5. Nooredin M, Ali P, Sajad Y, Mohammad Javad T, Hassan N, Payam A, et al. Effect of cold application on chest tube removal pain in heart surgery patients. Natl Res Inst Tuberc Lung Dis. 2018;17(1):29-36.

6. Vasseur BG. A simplified technique for closing thoracostomy incisions. Ann Thorac Surg. 2004 Apr;77(4):1467-8.

7. Kim MS, Shin S, Kim HK, Choi YS, Kim J, Zo JI, et al. Feasibility and safety of a new chest drain wound closure method with knotless sutures. Korean J Thorac Cardiovasc Surg. 2018;51(4):260-5.

8. Chae JK, Kim JH, Kim EJ, Park K. Values of a patient and observer scar assessment scale to evaluate the facial skin graft scar. Ann Dermatol. 2016;28(5):615.

9. Aliano K, Trostler M, Fromm IM, Dagum A, Khan S, Bui D. A comparison of barbed sutures and standard sutures with regard to wound cosmesis in panniculectomy and reduction mammoplasty patients. Plast Surg Int. 2016;2016:1-5.

10. Cortez R, Lazcano E, Miller T, Hein RE, Constantine RS, Anigian $\mathrm{K}$, et al. Barbed sutures and wound complications in plastic surgery: an analysis of outcomes. Aesthet Surg J. 2015;35(2): $178-88$ 